\title{
FOOD (IN) SECURITY AMONG THE COMMUNITY AT THE INDONESIA - MALAYSIA BORDER AT PANDEMIC COVID-19 ERA: A HUMAN SECURITY PERSPECTIVE
}

\author{
Sidik Jatmika \\ Afiliasi: Universitas Muhammadiyah Yogyakarta \\ Email: sidikjatmika@mail.umy.ac.id
}

\begin{abstract}
Abstrak
Artikel ini bertujuan untuk meneliti masalah ketahanan pangan di kalangan masyarakat di perbatasan Indonesia - Malaysia pada era Pandemi COVID-19 dengan menggunakan konsep Food Security, teori ketergantungan dan pendekatan keamanan manusia. Penelitian dilakukan menggunakan metode penelitian kualitatif untuk mengumpulkan dan menganalisis data primer dan sekunder. Data primer diperoleh melalui dokumen resmi dan wawancara mendalam dengan informan utama di antara rumah tangga Indonesia dari masyarakat di Indonesia - perbatasan Malaysia dan para pemimpin lokal. Sementara itu, materi yang diterbitkan dan dokumen online seperti buku, artikel jurnal, dan laporan berfungsi sebagai sumber data sekunder. Temuan ini menunjukkan bahwa pandemi COVID-19 menciptakan kerentanan terhadap kerawanan pangan di masyarakat perbatasan. Menyadari fakta ini, pemerintah harus mempertimbangkan untuk mengadopsi konsep keamanan manusia, yang menekankan pemberdayaan masyarakat sebagai kerangka dalam pembuatan kebijakan, dengan tujuan untuk memberantas kerawanan pangan di antara rumah tangga yang rentan dan untuk memastikan kesejahteraan setiap masyarakat Indonesia.
\end{abstract}

\begin{abstract}
This article aims to examine food security issue among the community at the Indonesia Malaysia border at Pandemic COVID-19 era by using the concept of Food Security; the theory of interdependence and the human security approach. The study is conducted using a qualitative research method to collect and analyze both primary and secondary data. Primary data were obtained through official documents and an in-depth interview with key informants among Indonesia households of the communities in Indonesia - Malaysia border and local leaders. Meanwhile, published materials and online documents such as books, journal articles and reports served as a secondary source of data. The findings indicate that pandemics COVID-19 create vulnerability to food insecurity at border community. Realizing this fact, the government should consider adopting the human security concept, which emphasizes community empowerment as a framework in policymaking, with the aims to eradicate food insecurity among vulnerable households and to ensure the well-being of every Indonesian.
\end{abstract}




\section{Introduction}

Indonesia is a country directly adjacent to Malaysia. This creates an opportunity for the Indonesian-Malaysian government in conducting trade relations, both in terms of the availability of basic groceries and the distribution of goods. The high demand and unavailability of domestic government to provide goods make this trade relationship are remarkable in meeting the availability of existing goods and can complement each other.

Indonesia-Malaysia diplomatic relations have been officially established since August 31, 1957, when Malaysia declared its independence. Indonesia as one of the countries that first recognized Malaysia's independence immediately raised the status of the Representative Office from the Consulate General to the Embassy of the Republic of Indonesia. These diplomatic relations make Indonesia the 11th largest export destination for Malaysia with a total of US\$ 5.22 billion in 2007 in trade relations conducted by Indonesia-Malaysia. Not only that, but the Indonesian Embassy is also actively organizing various activities such as trade exhibitions and exhibitions of Indonesian products to increase bilateral trade between the two countries. Malaysia is also not playing games in investing in Indonesia. Malaysia's total investment is $18 \%$ of the total foreign investment in Indonesia. The infrastructure development, insurance, and telecommunications sectors are expected to attract Malaysian investors to Indonesia, in addition to the automotive and power generation industries. Malaysia has also strengthened its investment with the merger between Bank Niaga and Bank Lippo. Mergers conducted by Malaysia's make CIMB (Bank Niaga) will master 58, $7 \%$ stake and Khazanah (Bank Lippo) 18.7\% stake. This is clear evidence that the Indonesia-Malaysia trade cooperation relationship has brought significant changes for the two countries. (Indonesia, 2021)

The close economic relationship between Indonesia and Malaysia, among others, is highly reflected in the crossborder trade between the two countries on the island of Sebatik, North Kalimantan. Sebatik Island is one of the 92 outermost small islands located in North Kalimantan Province and directly adjacent to the neighboring country, Malaysia. At first, Sebatik Island was part of Nunukan Regency, then based on Government Regulation No. 38/1996 which stated that the Sebatik area was turned into a subdistrict and since 2006, according to 
Regional Regulation No. 03/2006 which stated the division of Sebatik District into two regions, namely Sebatik District and West Sebatik District. Along with the implementation of the decentralization system, in 2011, the Sebatik area was divided into five sub-districts, namely Sebatik District, West Sebatik District, East Sebatik District, North Sebatik District, and Central Sebatik District. The strategic location on the border of Indonesia and Malaysia and the potential for abundant natural resources make Sebatik Island a strategic area across. (Ghafur, 2016) However, behind the various potentials, Sebatik Island has various problems, especially in managing the development and increasing food security in the region.

The total population in the Sebatik area of Indonesia, based on data from the BPS Nunukan Regency in 2019, that the population of Sebatik is 45,645 people. In Sebatik, Indonesia, there are 60 shops of which $30(50 \%)$ provide nine basic ingredients (gas, cooking oil, food). Uniquely, their food needs depend more on the Malaysian city of Tawau, which can be reached by boat within 15-20 minutes from Sei Pancang Harbor. From Sebatik Indonesia's perspective, farmers and collectors of agricultural products in the form of oil palm, cocoa, coffee, and bananas or fish caught are sold to Tawau by using large wooden boats across the Pancang river by utilizing a network of traders who have kinship relations with traders in Indonesia. Tawau, Malaysia. On the other hand, after marketing agricultural products or fish catches, traders buy various basic needs from Malaysia, such as rice, flour, cooking oil, granulated sugar to gasoline and LPG, most of which are commodity goods subsidized by the Malaysian government (Siburian, 2012). If food is imported from Indonesia (Makassar and Surabaya), you have to wait 2 to 3 days, so the price can be twice as expensive.

However, this trade relationship is in the midst of an outbreak of a disease that is spread through a virus, namely the Coronavirus or better known as COVID19. The Coronavirus pandemic is not just a health catastrophe. This virus has also caused chaos in the economic sector, especially in North Kalimantan (IndonesiaMalaysia) Cross-border. With the Coronavirus pandemic, economic activity has decreased both domestically and overseas. The latest Coronavirus outbreak has occurred since the end of 2019, started in Wuhan, Hubei Province, China. The 
virus was expected to have originated from bats that were transmitted to other animals before " hopping" to humans. Although the shape is similar, this virus has a different character, therefore it is called SARS-CoV-2 which causes COVID-19 (a disease caused by the 2019 Coronavirus). However, unlike SARS and MERS, which are contagious when the disease starts to get serious, in COVID-19 people can already infect the others in the first three days of being exposed to the virus. As a result, the rate of transmission of COVID-19 is very high. If SARS is about 3, MERS less than 1 , the rate of transmission of COVID-19 is $1,4-2.5$. (MOEDJIONO, 2020)

The latest Coronavirus outbreak has occurred since the end of 2019, started in Wuhan, Hubei Province, China. The virus was expected to have originated from bats that were transmitted to other animals before " hopping" to humans. Although the shape is similar, this virus has a different character, therefore it is called SARS-CoV-2 which causes COVID-19 (a disease caused by the 2019 Coronavirus). However, unlike SARS and MERS, which are contagious when the disease starts to get serious, in COVID-19 people can already infect the others in the first three days of being exposed to the virus. As a result, the rate of transmission of COVID-19 is very high. If SARS is about 3, MERS less than 1, the rate of transmission of COVID-19 is 1, 4-2.5. (Kesehatan, 11)

Epidemic control highly depends on awareness, alertness, and readiness of health infrastructure, starting from the management of the central and regional governments in implementing public health efforts, to facilities and health workers in treating patients. The world has become one unit due to the high mobility of people and goods. Therefore, there are no more diseases of other countries, we can all be affected.

The other thing which should be done by humans is maintaining the balance of nature. By consuming everything in moderation, eat only those that are safe and healthy. Thus, it can reduce the possibility of the virus hopping from wild animals to humans. As the same as the other Coronavirus infections, the clinical appearance ranges from asymptomatic, mild respiratory distress, pneumonia to severe respiratory distress, kidney failure, and death. Transmission of this virus can also be spread through splashes of liquid from sneezing and 
coughing. The incubation period is about 214 days, bias anya symptoms appeared on day 5. Amidst the Coronavirus outbreak, the Indonesian government demands the Indonesian people to keep their distance therefore the COVID-19 virus does not spread widely. Hence, those economic activities such as in markets, stalls, supermarkets, and others can improve their activities. (Indonesia I. D., 2020)

Following the increase in positive cases of Covid-19, since April 2020 the Malaysian Government has implemented a lockdown policy (Kompas, 2020), which has resulted in the closure of the national border gate on Sebatik Island. In fact, under normal conditions, Indonesian Sebatik residents are very dependent on food supplies from Malaysia. So, what is the impact of the Covid-19 pandemic on food security at the Indonesia-Malaysia border?

Figure 1. Map of Sebatik, North Kalimantan / Borneo (Indonesia-Malaysia

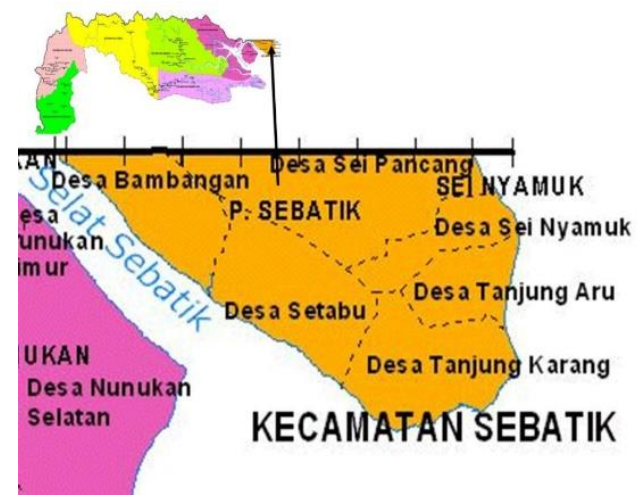

Border).

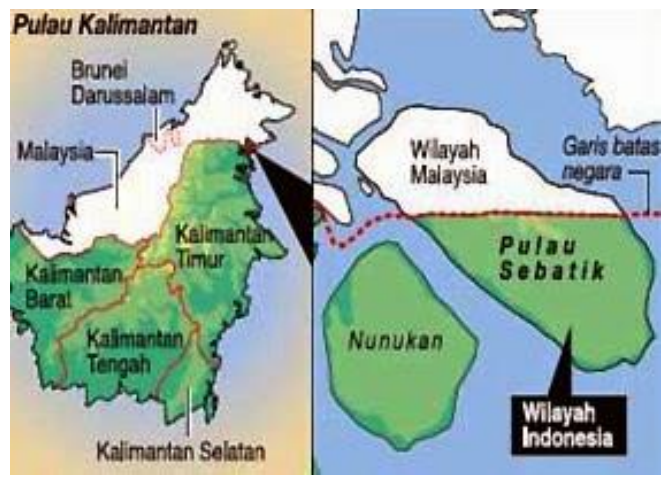

\section{Objectives And Benefits}

1. This research aims to examine the coping mechanisms adopted by Indonesian households among communities in the IndonesiaMalaysia border area by using the human security approach.

2. Enhance studies related to food security as a part of human security studies.

\section{Methodology}

The study is conducted using a qualitative research method to collect and analyze both primary and secondary data. Primary data were obtained through official documents and an in-depth interview with key informants among Indonesian households of the communities near the Indonesia -Malaysia border, local leaders, and academicians. Meanwhile, published materials and online documents such as 
books, journal articles, and reports served as a secondary source of data.

\section{Literature And Theoretical Review}

The novelty of this study uses various literature sources and theoretical foundations related to Food Security in the Border Using Scopus.com applications, Google Scholar; when the keyword is typed: food security and chain and border, it was found that 71 Scopus indexed journals published in the last 5 years (2017 - 2021). Furthermore, when processed with the VOSviewer application, a network visualization was found which contained various keywords and main relations related to this discussion, including trade, global supply chain, effect, crisis, epidemic.

Picture 1. Network Visualization: Food Security and Border

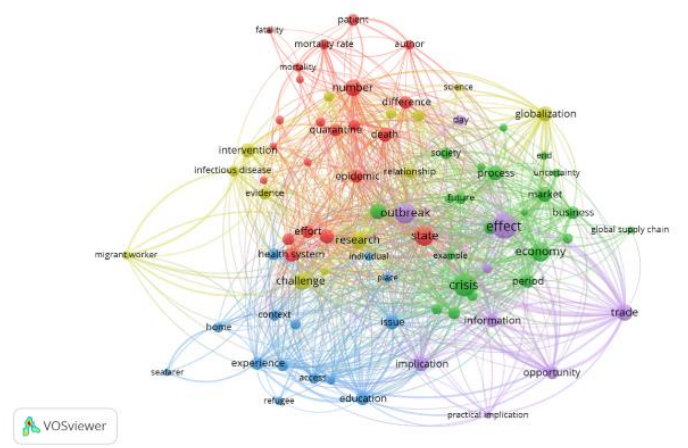

Several previous studies related to the study of Food (In) Security Among the Community at the Border; including exploring Amir K.N.K. and Mat B (B,

2021) examine the coping mechanisms adopted by Malaysian households among communities in the MalaysiaThailand border area by using the human security approach. These articles are useful to compare with cases at the Indonesian border in Malaysia.

Iese V.et.all, (2021) explain Impacts of COVID-19 on agriculture and food systems in Pacific Island countries (PICs): Evidence from communities in Fiji and Solomon Islands. COVID-19 mitigation measures including border lockdowns, social distancing, and restricted movements have been enforced to reduce the risks of COVID-19 arriving and spreading across PICs. To reduce the negative impacts of COVID-19 mitigation measures, governments have put in place a few interventions to sustain food and income security. Both mitigation measures and interventions have had a few impacts on agricultural production, food systems, and dietary diversity at the national and household levels. (all, 2021) Those articles are useful to analyze the impacts of COVID-19 mitigation measures, governments have put in place a few interventions to sustain food and 
income security on the Indonesia-Malaysia border.

Zeng S.(2021), by article Agricultural Supply Chain Risk Management in the Post-epidemic Era, explains that in the COVID-19 pandemic, China, as the first country to fight the epidemic, took measures such as social isolation, regional blockade, and traffic control, which had a positive effect on preventing the spread of the epidemic. (S, 2021) But the agricultural supply chain in the control area received a great impact; in terms of international epidemic prevention, all countries are strengthening their border blockade, safeguarding their food demand, and strict import and export quarantine measures which have a huge impact on the global flow of agricultural products, and the lack of imported agricultural products to supplement the supply security of China's agricultural products are under certain threat. In those paper, by sorting out the paths of the epidemic affecting the supply chain of agricultural products and the characteristics of China's agricultural supply chain, he deeply analyzes the sources of risks in China's agricultural supply chain under the epidemic and put forward suggestions such as strengthening the collaborative management of the agricultural supply chain, building a response mechanism and prevention mechanism for the quality and safety of agricultural products, constructing a logistics network suitable for the storage and transportation requirements of agricultural products, and accelerating the construction of a big data platform for the agricultural supply chain. Those articles useful to analyze the agricultural supply chain in the control area received a great impact; in terms of international epidemic prevention in Indonesia-Malaysia border.

Savelli C.J., et.all, (2021) by article The Utilisation of Tools to Facilitate CrossBorder Communication during International Food Safety Events， 19952020: A Realist Synthesis, describe that efficient communication and coordination are needed between countries to prevent, detect and respond to international food safety events. While communication tools, networks, and systems exist, current evidence suggests that they are only useful within contexts, and several only target specific geographic areas. (Savelli C.J., 2021) There is a need to unpack and explore the mechanisms of how and in what context such communication tools and their components are effective at facilitating international 
communication and coordination to keep food safe and mitigate the burden of foodborne disease around the world. Components of such communication tools may be adapted according to different contextual factors to promote, support, and improve their use. Improving international coordination and communication during international food safety events is in the interest of global health security and can mitigate the global burden of foodborne disease. That article is useful to understand Indonesia-Malaysia government coordination and communication during international food safety events is in the interest of global health security and can mitigate the global burden of foodborne disease, especially in their border area.

O'Brien S.et.all (2020) by article Investigation of a Foodborne Outbreak of Shigella sonnei in Ireland and Northern Ireland, December 2016: The Benefits of Cross-Border Collaboration and Commercial Sales Data describe a crossborder foodborne outbreak of Shigella sonnei that occurred in Ireland and Northern Ireland (NI) in December 2016 whilst also highlighting the valuable roles of sales data and international collaboration in the investigation and control of this outbreak. This outbreak investigation highlights the importance of international collaboration in the efficient identification of cross-border foodborne outbreaks and the value of using sales data as the analytical component of such studies. (Valerio V.C., 2020) That article is useful to understand the Indonesia-Malaysia crossborder impact of COVID-19 on sales data and international collaboration in the investigation and control of this outbreak, especially to control their impact on food security.

Valerio V.C. et.all (2021), by article Network Analysis of Regional Livestock Trade in West Africa, describe that In West Africa, long and complex livestock value chains connect producers mostly in the Sahel with consumption basins in urban areas and the coast. They mapped and characterized the trade networks, identified market communities, key markets, and their roles. Their findings support eliminating cross-border impediments and improving the condition of the regional road network, which limits intraregional trade and contributes to the high prices of food products in West Africa. Although with limitations, their study sheds light on the abstruse structure of regional livestock trade, and the role of trade communities and markets in West Africa. (V.C., 2001) That 
article is useful to map and characterized the trade networks, identified market communities, key markets, and their roles in the Indonesia-Malaysia border.

\section{Theoretical Framework}

\section{Food Security}

The Food and Agriculture Organization (FAO) is a specialized agency of The United Nations in which has goal to achieve food security for all and make sure that people have regular accaes enough high-quality food to lead active, healthy lives. With over 194 member states, FAO work in over 130 countries worldwide. FAO mention that "food security exists when all people, at all times, have physical and economic access to sufficient, safe and nutritious food that meets their dietary needs and food preferences for an active and healthy life". (World Food Summit, 1996) (Summit, 2006). This widely accepted definition points to the following dimensions of food security:

Food availability: The availability of sufficient quantities of food of appropriate quality, supplied through domestic production or imports (including food aid). Food access: Access by individuals to adequate resources (entitlements) for acquiring appropriate foods for a nutritious diet. Entitlements are defined as the set of all commodity bundles over which a person can establish command given the legal, political, economic and social arrangements of the community in which they live (including traditional rights such as access to common resources). Utilization: Utilization of food through adequate diet, clean water, sanitation and health care to reach a state of nutritional well-being where all physiological needs are met. This brings out the importance of non-food inputs in food security. Stability: To be food secure, a population, household or individual must have access to adequate food at all times. They should not risk losing access to food as a consequence of sudden shocks (e.g. an economic or climatic crisis) or cyclical events (e.g. seasonal food insecurity). The concept of stability can therefore refer to both the availability and access dimensions of food security.

\section{Interdependence Theory}

It is never too late for developing countries to pursue their remainder by reinforcing the capacities and capabilities of their countries thus they can transform themselves from the level of selfdependency to the level of mutual dependency or interdependence. It means 
that they conduct the transformation process from dependency into cooperation that is in balance with the field of economic politics that resulted in interdependent and complementary (complementation) of each other. (Archer, 1992)

The principle of Interdependence Theory stresses the mutual understanding between a party with the other parties to complement each other in meeting the needs of individual life that a-just and equal. There is no self-sufficient country in the world which able to sustain itself without having any relations with other countries. According to the arguments of Robert Keohane and Joseph Nye, the ideas of interdependence are based on two perspectives in viewing the distribution of reciprocal sacrifices produced by interdependence relationships, namely:

1. Characterized by the economy, means that interdependence will be able to meet the shortcomings and strengths of each party through the comparative advantage of society.

2. How is the distribution of profits and losses with a moderate definition from Rosecrance and Arthur Stein who divide it into 3 concepts:
1. Interdependence shows an interestbased relationship if the position of a country changes, then the other countries will be affected by the change.

2. Interdependence comes from the economic aspect which shows the relationship that happens when there is national sensitivity to external economic developments.

3. Interdependence involves a certain level of relationship which is disconnected will be very detrimental between them. (Yanuar, 2006)

By looking at the basis of the interdependence theory as described above, the relationship of economic cooperation between Indonesia and Malaysia is a steppingstone to the transformation process from dependence to balanced cooperation. In this case, the economic relations carried out by the central and regional governments in Indonesia to Malaysia play a role in complementing the availability of goods between Indonesia and Malaysia and facilitating trade distribution. Indirectly, this also makes it easier for MSMEs in North Kalimantan to meet basic needs and make it easier to distribute goods both abroad and within the country. (Yani, 2005) 


\section{Analysis}

The influence of COVID-19 on the availability of basic groceries and distribution of goods for MSMEs across North Kalimantan borders in the IndonesiaMalaysia economic relationship consists of three parts. First, the decline in economic activity in North Kalimantan, which is marked by a decline in consumer demand. Second, the difficulty of economic actors, which in this case is MSMEs, in meeting the availability of basic groceries and the difficulty of distributing goods to domestic and foreign countries with complicated health procedures. Third, the government's efforts in dealing with the COVID-19 disease outbreak for MSMEs affected by the virus.

\section{Discussion}

\section{Indonesia-Malaysia Socio-}

\section{Economic Cooperation}

Indonesia and Malaysia have been working together for a long time. There have been a lot of cooperative relations between Indonesia and Malaysia until nowadays, thus creating a very good relationship between the two countries. The cooperation carried out by Indonesia and Malaysia covers various fields, including the economic field, education sector, social sector, and anti-terrorism cooperation. In the field of education, Indonesia and Malaysia establish a relationship by holding student exchanges every year. In the economic field, both countries open economic opportunities for investors, which for Indonesia is very helpful for the government in alleviating unemployment. Investors from Malaysia invest a lot in the palm oil plantation industry.

In this area of palm oil plantations, Indonesia-Malaysia have agreed to strengthen markets, increase trading capacity, create trade facilities, and participate in investment and business missions. Currently, Indonesia-Malaysia controls $80 \%$ of the world's palm oil production. This is certainly beneficial for both parties. Moreover, in the social sector, in Malaysia, many Indonesian workers work as household servants, medical officers, construction workers, and other professionals. One of Indonesia's border areas that has a fairly high level of activity and trade-economic interaction is the border between North Kalimantan and Tawau, Malaysia. We can see this from the longstanding traditional trade between communities in the Cross Border of North Kalimantan. The interaction behavior of 
border communities in the two countries is triggered by ethnic and linguistic similarities. These reasons then emerge traditional social and economic relations between them. Based on these factors, of course, it becomes the basic capital to conduct mutually beneficial trade interactions. (Putra, 2015)

In regulating the traffic of goods (trade) between communities at the border, Indonesia and Malaysia have agreed in the form of a Border Trade Agreement (BTA) or "Agreement on Cross-Border Trade between the Government of the Republic of Indonesia and the Kingdom of Malaysia." The agreement was signed on August 24, 1970, in Jakarta. One of the contents of the agreement is in the form of Socio-Economic Cooperation between Malaysia and Indonesia or Sosek Malindo in short. The vision of the Sosek Malindo collaboration is: "Improving the welfare of the people of the two regions through Sosek Malindo cooperation towards 2020. For the vision of this collaboration to be realized, the missions carried out are first, creating socio-economic and cultural conditions that are conducive to the welfare of the people of each region; second, increasing economic cooperation that is just and mutually beneficial and oriented towards environmental

sustainability; third, increasing

sociocultural cooperation through improving the quality and empowerment of human resources in the two border areas. Border cooperation between the two countries of the Republic of Indonesia-Malaysia initially began with the security sector in 1967. The agreement on the Regulations in the Security Sector of Border Areas was then revised for the first time in 1972 and then received a second revision in 1984. In this second revision, cooperation in Crossborder areas has expanded the scope of cooperation to cover various types of fields, namely ideology, politics, social, culture, and also the economy. (A Mutia, 2014)

Since 1995 the scope of the MalaysiaIndonesia Socio-Economic Cooperation in the context of implementing Foreign Cooperation has only been to the State of Sabah. The border areas that are actively participating in this collaboration are some of the border sub-districts in Nunukan District, while other areas such as Malinau and Kubar Districts, whose border districts are not included. However, after going through several proposals, and discussions at several meetings between JKK/KK Sosek Malindo Pusat, Indonesia-Malaysia, finally, these sub-districts could be temporarily 
included, not only between the Province and the State of Sabah but also with the State of Sarawak. (Nugrahaningsih, 2015)

The duties and functions of the Regional/State Level Sosek Working Groups are:

First, determining

projects that will bring about a balance of development and security in the common border area. Second, determining projects in the Regional Province of the State that bring benefits to both parties and may be used together. Third, determining joint projects. Fourth, planning ways to implement socio-economic development in the border areas of each province/region following the provisions stipulated by the working group at the central level. Fifth, carrying out the exchange of information regarding socio-economic development projects in shared border areas. Sixth, submit the KK and report to the Joint Working Group at the Central level regarding the implementation of the Indonesia-Malaysia Border SocioEconomic Development.

Afterward, as many as seven papers were discussed in the 18th Technical Meeting of the Working Group/Corporate Office for Social Economic Development (KK/JKK Sosek Malindo) at the East
Kalimantan Province/Sabah Ranking, namely; Development of Land Crossborder Posts, Development of Sea-Border Posts, Smuggling Prevention and Control, Cooperation in Social Relations, Cooperation in Education, Cooperation in Health, and Cooperation in the Field of Economy and Trade.

Based on the results of an interview we conducted with Mr. Harman as the Head of Trade of Nunukan Regency on September 18, 2020. He said that if we focus directly on the process and things that happen at the border, we may know that the border on Sebatik Island itself is tightly guarded by the Indonesian National Army. This is supported by the evidence when we conducted my research in Sebatik, we found many guard posts, and the national border is guarded by the Indonesian National Army (TNI). Not forget to mention that TNI is also tasked with inspection of traffic entering and leaving Indonesia, be it goods, people, and services to ensure security and health to ensure the safety of the Indonesian people in Sebatik, especially during this COVID19 pandemic. These border guard officers are not only guarded by TNI. The Indonesian and Malaysian military cooperate by building several special 
posts on the border containing Joint Personnel who jointly maintain the sovereignty of the country, both Indonesia and Malaysia. This makes balanced cooperation between Indonesia and Malaysia in national defense cooperation at the border. (Harman, 2020)

\section{The Effect Of Covid-19 On}

\section{MSMES}

The border crossing between North Kalimantan and Malaysia has never been separated from the traffic of goods out and into the country. The efforts of border communities in providing for their daily economy require them to expand their trade network. However, at the end of 2019, there was an outbreak of a disease that we know as the Coronavirus. Coronavirus is a virus that attacks the respiratory system. The disease caused by this viral infection is called COVID-19, this Coronavirus causes mild disturbances in the respiratory system, severe lung infections, and even causes death. Coronavirus can attack anyone, such as the elder, adults, children, and infants, including pregnant women and breastfeeding mothers. This virus was first discovered in the city of Wuhan, China. This virus spreads very quickly and has spread to almost all countries, including our country, Indonesia, in just a few months. (Pane, 2021)

This virus is transmitted through droplets of phlegm from the respiratory tract in a crowded closed room and with poor air circulation. By looking at the dangers posed by this virus, several countries have implemented policies to impose lockdowns to prevent the spread of the Coronavirus. This is also done at the border by the two countries, both Indonesia and Malaysia. In Indonesia itself, a LargeScale Social Restriction (PSBB) policy was implemented to suppress the spread of this virus. The term PSBB itself emerged from President Joko Widodo as an effort that must be made to fight the COVID-19 pandemic. PSBB itself is a restriction on certain activities of residents in an area suspected of being infected with the Coronavirus to prevent the possibility of spreading further. Thus, many activities involving the public must be limited such as offices, markets, religious activities, and public transportation. (Pane, 2021)

The restrictions imposed by the government to suppress the spread of the Coronavirus directly limit the movement of economic actors in the amount of production and distribution of goods. Market activities can no longer be 
found in the application of PSBB so that economic actors, especially MSMEs, experience a decrease in income and production demand. Based on data from Bank Indonesia (BI) reports, MSMEs exporters are the most affected, which is around $95.4 \%$ of the total exporters, MSMEs engaged in the handicraft product sector and supporting tourism are affected by $89.9 \%$. While small sectors most affected by the pandemic COVID-19 is the agricultural sector, which amounted to 41 , $5 \%$. The influence of the exporting MSMEs sector is the highest $(95.4 \%)$, this is a direct impact of the PSBB, which causes the space to reach the production target to experience obstacles. Social distancing, which we know as social distancing, is also a factor in triggering distribution barriers, resulting in a decrease in sales turnover for MSMEs actors. (Syamsudin, 2020)

In Sebatik, Indonesia, there are 60 shops of which $30(50 \%)$ provide nine basic ingredients (gas, cooking oil, food). After conducting interviews with 6 residents of Sebatik who work as food ingredients traders, various evidences were obtained that the lock-down policy carried out by the Malaysian Government following the spread of the Covid-19 pandemic since
March 20, 2020, has caused a sharp increase in prices. This happened because, supply from Malaysia only needed a trip of 20 - 30 minutes by boat or ship, and it stopped. Because internal Indonesian supplies must be imported from Makassar and Surabaya, which takes 2 to 3 days, has caused prices to increase to 2 or 3 times the normal price. Even in the interior of North Kalimantan Province, prices can skyrocket up to 100 times the normal price. For example, the Indonesian National Daily, Kompas (Zulfiqor, 2020) Because of the Malaysia Lockdown, the price of LPG at Krayan is Rp. 1.5 million (normal is only Rp. 15 thousand), Cement is Rp. 1.8 million per Zak (normal is only 50 thousand).

Based on the results of the interviews we conducted with Mrs. Siti Hasna, as the Head of the Empowerment and Development of Cooperatives and MSEs, Nunukan Province, on September 18, 2020. She explained that MSME products in North Kalimantan are more focused on local basic ingredients, one of which is seaweed which is processed into crackers, even frozen food such as pentol, sausage, and nuggets have been produced in Nunukan and East Sebatik. The superior products in Sebatik vary from Middle Sebatik to banana plantation products 
which are processed into chips, banana flour while East Sebatik has carried out fish as amplang and fish balls. (Hasna, 2020)

The basic ingredients for processing products are taken from Indonesia and Malaysia, with the efforts and creativity of MSMEs across the borders of North Kalimantan making the results of their natural resources processed into more valuable products. Many factors support these activities, such as opening new job opportunities, increasing income for MSME actors across the border in North Kalimantan. Focus in the Sebatik Island, there are a lot of home industries that process the results of their natural resources so that many SMEs products can be found there. Starting from the basic ingredients of bananas, seaweed, fish, and many more, where the results of these natural resources make various kinds of products that are sold both at home and overseas. MSME actors across borders also export to neighboring countries but in small quantities. Products that are exported are products that have less demand in the country, thus MSMEs actors sell their products in batches without going through the export-import rules by customs, but upon arrival in Malaysia, Malaysia will re-brand them. This is very evident in the Cake Bangke" Home Industry in East Sebatik. (Hasna, 2020)

Training for economic actors across North Kalimantan Borders during the COVID-19 pandemic was held by the North Kalimantan provincial government. In East Sebatik, training on $e$ commerce and branding has been held. For branding training, by the provincial government of North Kalimantan, branding mentors were brought directly from the "Bandung Creative House". The training provided starts from choosing product names, how to package products, and packaging materials. Meanwhile, e-commerce is imported directly from Jakarta. MSME actors are formed in groups and joined to the WhatsApp Group, to facilitate sharing between MSME actors and consult with mentors regarding sales. (Hasna, 2020)

During the pandemic, the availability of staple goods in North Kalimantan Crossborder decreased. This is due to the limited economic movement both from the community and from the government, the supply of goods entering the Sebatik becomes difficult, and the movement of people to go to the sea and fields is limited. These are resulting in the decrease of production, it is difficult to do marketing, 
and people's purchasing power decreases. Since the products of these MSME actors are dominated by snacks, during this pandemic period of visitors coming to Sebatik Island decreased so that snack sales also decreased, because snacks are the hallmark of souvenirs from Sebatik Island, one of which is Cake Bangke. Not only that, the Sebatik community, the majority of whom are also fishermen, and their fish that are usually exported to Malaysia (Tawau) during the pandemic period was temporarily stopped due to the implementation of the lockdown in both Malaysia and Indonesia. Hence, the fish caught by the Sebatik community fishermen are only sold domestically (Nunukan). (Hasna, 2020)

This is reinforced by the data we obtained from MSME actors on the island of Sebatik. MSME actors admit that the COVID-19 pandemic has resulted in unstable goods availability and income. In this study, we interviewed 6 MSME actors on the island of Sebatik with the following data acquisition.

a) Mr. Sutrisno: $\mathrm{He}$ is an immigrant from Demak, Central Java, which sells Tahu Tek in Sebatik Island. He admitted that with the COVID-19, he experienced an increase in income, according to $\mathrm{Mr}$. Sutrisno, during the COVID-19 pandemic, more and more Sebatik people were looking for food in his place. According to Mr. Sutrisno, the availability of goods in Sebatik during the COVID-19 pandemic did not change with the period before the COVID-19 pandemic, because Mr. Sutrisno used several ingredients from Malaysia such as sugar, soy sauce, and oil. However, tofu, eggs, vegetables that he uses come from Indonesia. According to Mr. Sutrisno, the most difficult to find is $3 \mathrm{~kg}$ gas cylinders from Indonesia, which are sometimes not available when gas cylinders are exhausted and forced to use gas cylinders from Malaysia. (Sutrisno, 2020)

b) Mrs. Sri Muryati: She is an immigrant from Madiun, East Java who sells Nasi Kuning on the Sebatik Island. Sri Muryati's mother admitted that she felt the impact of the COVID-19 pandemic on her sales. During the COVID-19 pandemic, sales decreased, especially in the first 5 days of 
COVID-19 starting to enter Sebatik Island. According to her, this is because the Sebatik community prefers to stay at home to avoid being exposed to the virus, hence, not many people come to eat at Mrs. Sri Muryati's place. However, in meeting the availability of basic commodities, Mrs. Sri Muryati did not experience any difficulties, only $3 \mathrm{~kg}$ gas cylinders from Indonesia were not always available when needed. Mrs. Sri Muryati uses all her groceries ingredients from Indonesia, she thinks that the groceries she uses from Indonesia do not spoil the original taste of her Nasi Kuning. (Muryati, 2020)

c) Mr. Sarlan: $\mathrm{He}$ is an exporter of boneless Milkfish (Bandeng). Mr. Sarlan usually exports his fish to Malaysia, especially in Tawau. Mr. Sarlan admitted that he felt the change with the COVID-19 pandemic in his sales. During the pandemic COVID-19, he at all does not export its boneless Milkfish to Malaysia. This is due to the declining number of boneless Milkfish enthusiasts during the
COVID-19 pandemic. Not only the declining numbers of demand, but the production levels also decreased due to restrictions on the movement of Mr. Sarlan's workers to go to sea looking for fish. Currently, Mr. Sarlan only sells his boneless Milkfish in Nunukan and Tarakan. (Sarlan, 2020)

d) Mrs. Cholilatul: She is a seller of various chips from Tanjung Selor. Mrs. Cholilatul sells various types of chips such as banana chips, cassava, tempeh, bitter melon, and others. Mrs. Cholilatul usually sells her chips by renting a place at supermarkets and exports her products to Malaysia approximately once a month, due to the high demand for chips from Tawau. However, since the arrival of the COVID-19 virus, the demand for chips has begun to decline and the implementation of the lockdown has also limited trading activities and distribution of goods. In meeting her basic needs ranging from gas cylinders, oil, bananas, and others, Ms. Cholilatul did not experience any difficulties. (Cholilatul, 2020) 
e) Mr. Markup: $\mathrm{He}$ is a seller of banana and taro chips in Tanjung Selor. In selling his chips, Mr. Markup relies on the products of his garden, he has a banana and taro garden which is not far from his house. Mr. Markup himself usually sells chips by renting a place at supermarkets. However, with the COVID-19 pandemic, Mr. Markup experienced a decline in sales, which according to Mr. Markup was caused by the implementation of the lockdown where there are not many tourists who visited Tanjung Selor and bought souvenirs. (Markup, Penjual Aneka Kripik, 2020)

f) Ms. Dila: She is a student from one of the campuses in Samarinda who is returning to her village on the island of Sebatik. Ms. Dila feels the impact of this COVID-19 pandemic. She said that due to the COVID-19 pandemic, she was obliged to stay at home and conduct online lectures, therefore Ms. Dila chose to return to her hometown and help her parents sell at the Milkshake shop owned by Ms. Dila's parents. According to her, during the COVID-19 pandemic, the shop was empty of visitors, no one gathered to hang out at Ms. Dila's shop. (Markup, 2020)

Based on the data we have obtained; we conclude that the impact of the COVID19 virus pandemic has been felt by SMEs across North Kalimantan. This disease outbreak has changed the economic behavior of people in Cross Borders in North Kalimantan, the people who were initially busy doing transactions such as buying and selling in the market became desert and chose to stay at home to maintain their health and safety. The COVID-19 pandemic has also resulted in the availability of staple goods in North Kalimantan Cross Borders to be scarce or delivery delays due to obstacles to the distribution process caused by the lockdown and massive purchases made by the community in meeting their basic needs due to excessive fear.

This has resulted in MSME actors only relying on basic groceries from agricultural products in the area itself. Later, with the view from the social behavior of Sebatik Island itself that is directly adjacent to Malaysia, it is not surprising that people on the border have the same habits. While we were on Sebatik Island, we often 
encountered buying and selling transactions using Malaysian Ringgit. This is indeed true, traders in Sebatik receive two currencies at once, economic actors in Sebatik receive payments in Rupiah and Ringgit. Likewise, with the language used, the people on Sebatik Island use 2 languages, namely Indonesian and Malay.

The level of dependence of the Indonesian people on Sebatik Island for basic

commodities on Malaysian products is already very rampant on Sebatik Island. Many factors make MSMEs in Sebatik using basic groceries from Malaysia because they have several advantages such as easy-to-get materials, cheaper prices, cleaner, and guaranteed quality, different flavors, and so on. It is very easy to find various Malaysian goods or products from supermarkets or small kiosks. Those things happen because it is natural that border territories are adjacent to each other, it is expected to make impartial cooperation and interdependence between Indonesia and Malaysia.

Which we need to know that Malaysia also has a dependence on the results of the resources owned in Indonesia. According to data, I obtained from the Trade Office in Nunukan Regency,
Indonesian people, especially those at the border, are often flooded with requests for seafood and agricultural products such as tuna, bananas, banana leaves, and other spices.

\section{Government Effort}

The rapid and massive transmission of the Coronavirus has forced the government to make an immediate decision. Large-Scale Social Restrictions (PSBB) is the government's choice in reducing the number of COVID-19 transmissions. Life is reluctant to die, doesn't want to, that's what can be likened to the conditions experienced by MSMEs actors amid the current COVID-19 pandemic. The government is aware that this PSBB policy has a huge impact on the economy. However, the government must make a choice, between saving economic interests or the safety of citizens. With full calculation and the consequences of the risks, the safety of citizens becomes the most important thing of all. The PSBB policy does not only limit the business activities of MSME actors, but almost all business fields, be it large-scale, even nonformal workers are affected by this policy. Medium and large-scale business sectors in the tourism sector and their 
derivatives such as hotels, restaurants, cafes, travel, entertainment, and transportation centers.

Before the first phase of PSBB which was implemented starting April 10, 2020, the government had first urged companies to implement work from home and learning activities at home for students and teachers. Data from the Indonesian Hotel and Restaurant Association (PHRI) dated April 13, 2020, noted that almost 1/642 hotels and 6,800 restaurants have closed throughout Indonesia, and it has the potential to increase if the COVID-19 outbreak is prolonged. This figure does not include the entertainment business sector, which amounts to thousands of units. Hotelscale businesses with strong infrastructure and management are experiencing a slump, we can imagine how the fate of MSMEs actors will be. The condition of MSMEs during the COVID-19 pandemic is very vulnerable, and it is certain that millions of MSMEs are dying and have even closed their businesses. (Kompas, 2020)

If we reflect on the 1998 monetary crisis and the 2008 global financial crisis, when many large companies collapsed, on the other hand, the MSMEs sector appeared to be the savior and supporter of the national economy. The resilience of
MSMEs is the main capital, which has brought the national economy to safety from the crisis, and slowly the economy can recover. MSMEs at that time were able to drive the grassroots economy and maintain people's purchasing power. However, now the situation is not much different. MSMEs are no longer strong and cannot be relied on as a support for the nation's economy. The market share owned by MSMEs is in the form of people's daily needs, both clothing, and food, which are currently narrowing. In this narrow space of movement, the various products prepared by MSMEs actors cannot make transactions that can move the economy and the circulation of money. The profile of MSMEs in Indonesia consists of three major clusters, namely producers, trading businesses, and services. Producers generally produce a variety of foods and beverages, such as various snacks, meatballs, chips, noodles, cakes, and others. Also, various clothing such as clothes, bags, shoes, sandals, crafts, and other creative industries, then the commercial enterprise vendors include five restaurants, cafes, shops, groceries stores, and others, and as well as general services such as workshops, salons, clinics, logistics, design, printing and so on. The market share of all MSME business fields will be largely determined 
by the movement of people as consumers or customers. The longer the PSBB policy is carried out by the government, the advice of MSMEs actors will be more uncertain and even MSMEs actors will slowly close their business. Under these conditions, MSMEs practically no longer have a contribution to make in maintaining national and regional economic growth. This contrasts with conditions in normal times, where MSMEs account for $60 \%$ of the gross domestic product (GDP) nationally and economic growth, which is supported by household consumption, is dominantly driven by this sector. Including its contribution to employment, which reached $96 \%$ of the 133 million workforces nationally and contributed $14 \%$ of total exports. The impact of COVID-19 is indeed very difficult for them, MSMEs actors, it can even be classified as an extraordinary incident for MSME actors. It is very ironic the conditions experienced by MSME actors today, who must bear the hardships of business due to COVID-19. (Simanjorang, 2020)

This is a very difficult situation for SMEs and other large-scale businesses. Making the government look for ways to improve the current state of the economy in Indonesia. Complaints after complaints from the public are continuously voiced, therefore on June 1, 2020, the government has enacted the New Normal. New Normal itself is a step or effort taken to increase the productivity of the community which was stopped during the implementation of the PSBB. In the implementation of the New Normal, the government has considered carefully, and with the hope that everything can return to the way it was before. With the implementation of the New Normal, shopping centers, public places, tourist attractions, markets, schools, and campuses can operate again with a note that they must comply with health protocols. The government hopes that the implementation of this New Normal can be a step to accelerate the handling of the spread of the COVID-19 virus in the health, education, social and economic sectors in Indonesia. The government is actively making various efforts so that the balance of health and the economy can improve together. In restoring the economy, the government is trying to answer the problems that exist in the business sector, especially Micro, Small, and Medium Enterprises (MSMEs). MSMEs are indeed more affected, sales decline, financial difficulties to pay in installments, and so 
on. Many efforts have been made by the government to save MSMEs during the COVID-19 pandemic. The support of MSMEs is the government's main concern in terms of economic recovery. (Cahya, 2020)

This is reflected in the budget allocation for the National Economic Recovery Program (PEN) and the MSMEs stimulus that has been issued. The total budget spent on MSMEs in the 2020 PEN 2020 reached Rp123.46 trillion, while for 2021, the Government has budgeted Rp48.80 trillion. As of 3 November 2020, it was realized $76 \%$ or equivalent to $\mathrm{Rp} 93$, 48 trillion. Realization People's Business Credit (KUR) January 2020 until October 31, 2020, amounted to Rp148, 38 trillion, or $78.9 \%$ of the target in 2020 amounting to Rp190 trillion, and was awarded, 4.5 debtors. Which total outstanding KUR since August 2015 amounted to Rp194, 05 trillion with NPLs around $0.70 \%$. The distribution of KUR during the COVID-19 pandemic is very sharp. From Rp18,99 trillion in March 2020 amounted to Rp4,76 trillion in May 2020. However, gradually KUR has risen back to the distribution in October amounted to Rp17, 72 trillion. KUR during 2020 had a scheme namely, super micro KUR (3, $02 \%)$, micro
KUR (65.74\%), small KUR (31.02\%), and KUR placement of migrant workers (0.23\%). (KOMINFO, 2020)

The pandemic is expected to last for quite a long time, and only adaptive and innovative MSMEs will be able to survive in taking advantage of the changing market situation amid the COVID-19 pandemic. "Said the Minister of Cooperatives and SMEs Teten Masduki". In the opening of the training with the theme "KUKM Exist and Able to Adapt in the COVID-19 Pandemic and the New Normal Era" Teten Masduki explained that the government did not remain silent, a series of policies had been carried out to help MSMEs and Cooperatives. MSMEs, in this case, are severely affected, so the government assists in the form of social assistance or social assistance. Meanwhile, MSMEs experiencing financing difficulties while their business activities are still ongoing will be given a 6-month interest subsidy loan restructuring as well as tax breaks, as well as loans with 3 percent interest. Then, for MSMEs that have not been touched by banking (unbankable), a productive Banpres is given in the amount of Rp. 2.4 million. This assistance is given to the person concerned until the end of September 2020 and is targeted to reach 
100 percent. If in the first quarter of 2021 the economy is still sluggish, then the two aids, namely restructuring and the productive Banpres for microbusinesses, will most likely continue. In the 2020 APBN, there is an allocation of $\mathrm{Rp}$. 307 trillion for $\mathrm{K} / \mathrm{L}$ (Ministry/Agency) expenditures that can be utilized by MSMEs, although in practice it is still around 8 percent. Therefore, the Cooperative and SMEs Ministry also worked with LKPP (the Policy Institute for Procurement of Goods / Services to accelerate the absorption of the cooperation is also carried out by the Ministry of Stateowned Enterprises (SOEs), which for the procurement of goods and services, including infrastructure whose value below 19 billion, was allocated to SMEs. This policy is currently only followed by 9 SOEs and is planned to apply to all SOEs in 2021 . The government also provides a means of transformation for MSMEs to be able to enter the digital market, by encouraging MSMEs to enter the marketplace. So that shopping through the marketplace will become a trend. This will provide access as widely as possible to MSMEs and can be connected to digital marketplaces. (Nugroho, 2020)
One of the efforts made by the government that has been implemented in the Nunukan Regency is in the form of business capital assistance. By collecting data on business actors registered in each cross-border area of North Kalimantan, the government is collaborating with Bank Indonesia (BI) and Bank Rakyat Indonesia (BRI). The business capital can be disbursed directly by MSMEs actors registered with BRI. This disbursement of venture capital is not carried out regularly, but only once disbursement of

Rp. 2,400,000. In addition, the Nunukan district government also assists in the form of business capital to micro, small and medium enterprises whose budget sources come from

the Regional Incentive Fund or DID that worth 2 billion which will later be distributed to 1000 MSMEs actors across North Kalimantan Cross Borders so that the funds received are: around Rp. 2,000,000 to each business actor. (Nugroho, 2020)

Based on the data we obtained while in Sebatik, by going directly to the border and digging up data directly to MSME actors. In general, we can conclude that the COVID-19 pandemic has had a profound impact on people's lives in Sebatik. The COVID-19 pandemic has changed the 
economic conditions of SMEs. Demand is gradually decreasing or not at all, which is exacerbated by the implementation of the lockdown that has been decided by the government. Seeing the worsening condition of MSMEs, the government did not just remain silent by assisting and made a new policy, namely the New Normal which was expected to be able to change this slumping economic condition so that it could recover. The points regarding changes in economic conditions after and before the COVID-19 pandemic on the availability of goods in North Kalimantan Cross Borders as well as the efforts that have

been made by the government are simplified in the form of a table as follows.

\begin{tabular}{|l|l|l|}
\hline No & $\begin{array}{l}\text { Conditions Before } \\
\text { Pandemic }\end{array}$ & $\begin{array}{l}\text { Conditions } \\
\text { During } \\
\text { Pandemic }\end{array}$ \\
\hline 1 & $\begin{array}{l}\text { Supplies of basic } \\
\text { ingredients that are } \\
\text { easy to get }\end{array}$ & $\begin{array}{l}\text { Supplies of } \\
\text { basic goods are } \\
\text { difficult to } \\
\text { obtain (due to } \\
\text { the } \\
\text { implementation } \\
\text { of } \\
\text { the lockdown) }\end{array}$ \\
\hline 2 & $\begin{array}{l}\text { Easy distribution } \\
\text { of goods abroad } \\
\text { and within the } \\
\text { country }\end{array}$ & $\begin{array}{l}\text { It is difficult to } \\
\text { distribute } \\
\text { goods abroad } \\
\text { and within the } \\
\text { country due to } \\
\text { the } \\
\text { implementation } \\
\text { of } \\
\text { lockdown }\end{array}$ \\
\hline
\end{tabular}

\begin{tabular}{|c|c|c|}
\hline 3 & $\begin{array}{l}\text { High demand from } \\
\text { consumers }\end{array}$ & $\begin{array}{l}\text { Decreased } \\
\text { demand from } \\
\text { consumers and } \\
\text { the purchasing } \\
\text { power of the } \\
\text { public }\end{array}$ \\
\hline 4 & $\begin{array}{l}\text { Markets and small } \\
\text { kiosks owned by } \\
\text { SMEs are always } \\
\text { crowded } \\
\text { buyers }\end{array}$ & $\begin{array}{l}\text { Markets and } \\
\text { small kiosks } \\
\text { are empty of } \\
\text { buyers because } \\
\text { of the } \\
\text { implementation } \\
\text { of the } \\
\text { lockdown and } \\
\text { public } \\
\text { awareness of } \\
\text { maintaining } \\
\text { health and } \\
\text { obeying the } \\
\text { government's } \\
\text { appeal to } \\
\text { always stay at } \\
\text { home }\end{array}$ \\
\hline
\end{tabular}

Later the government policies that have been carried out to reduce the number of COVID-19 transmissions are still producing results that can be said to still have positive and negative impacts. Starting from the beginning of the spread of COVID-19 in Indonesia and then to the current condition, we think the efforts and policies given by the government have been well thought out and well thought out. We can see this from the positive steps in the lockdown or PSBB policy taken by the government to suppress the spread of COVID-19 but harm economic growth in Indonesia. As soon as the government 
implemented the New Normal policy to increase the productivity of the community, which had stopped during the implementation of the PSBB, however, this is harmful due to the increasing number of COVID-19 patients. Not only that, to save the existence of MSMEs actors in Indonesia, the government also provides social assistance in the form of business capital. According to the authors, the policies implemented by the government may not be the best, but they are appropriate to maintain the safety of the Indonesian people and the stability of the Indonesian economy.

\section{Discussion}

The findings in this article have several differences from several previous studies related to the study of food security in the Indonesia-Malaysia border. The findings of this article regarding the various problems of hampering the distribution of goods at the Indonesia-Malaysia border due to the Malaysian government's lockdown policy and the Indonesian government's physical distancing are different from the study of Amir K.N.K. and Matt B (B, 2021) examine fluently food chain distribution among communities in the Malaysia-Thailand border area.
The findings of this article regarding the Indonesian government's low mitigation capacity for the food chain in the IndonesiaMalaysia border are different from the findings of Iese V.et.all, (2021) explaining the impacts of covid-19 on agriculture and food systems in pacific island countries (pics): evidence from communities in fiji and solomon islands in which governments have put in place some interventions to sustain food and income security. Both mitigation measures and interventions have had some impacts on agricultural production, food systems, and dietary diversity at the national and household levels. (all, 2021)

The findings of this article regarding the weakness of the Indonesian government the agricultural supply chain in the control area received a great impact; in terms of international epidemic prevention in Indonesia-Malaysia border; different from the findings of Zeng S. (2021), by article Agricultural Supply Chain Risk Management in the Post-epidemic Era, explains that in the COVID-19 pandemic, China strengthens to the collaborative management of the agricultural supply chain, building a response mechanism and prevention mechanism for the quality and safety of agricultural products, constructing 
a logistics network suitable for the storage and transportation requirements of agricultural products, and accelerating the construction of a big data platform for the agricultural supply chain. (S, 2021)

The findings of this article regarding the low quality of the mechanism on how and in what context these communication tools and their components are effective in facilitating international communication and coordination to maintain food security and mitigation at the Indonesia-Malaysia border; In contrast to the findings of Savelli CJ, et.all, (2021) by article Utilization of Tools to Facilitate Cross-Border Communication during International Food Safety Events, 1995-2020 explains that efficient communication and coordination is needed between countries to prevent, detect and respond to safety events international food. While communication tools, networks, and systems exist, current evidence suggests that they are only useful in certain contexts and some only target specific geographic areas. (Savelli C.J., 2021)

The findings of this article are about the lack of sales data and international collaboration between Indonesia and Malaysia authority's border in the investigation and control of this outbreak, especially to control their impact on the food security; also different from the findings of O'Brien S.et.all (2020) by article Investigation of a Foodborne Outbreak of Shigella sonnei in Ireland and Northern Ireland, December 2016: The Benefits of Cross-Border Collaboration and Commercial Sales Data describe a crossborder foodborne outbreak of Shigella sonnei that occurred in Ireland and Northern Ireland (NI) in December 2016 whilst also highlighting the valuable roles of sales data and international collaboration in the investigation and control of this outbreak. (O'Brien S., 2020)

Finding of this article is lack of mapped and characterized the trade networks, identified market communities, key markets and their roles in the Indonesia-Malaysia border; different with Valerio V.C. et.all (2021), by article Network analysis of regional livestock trade in West Africa, describe that In West Africa, long and complex livestock value chains connect producers mostly in the Sahel with consumption basins in urban areas and the coast. They mapped and characterized the trade networks, identified market communities, key markets, and their roles. Their findings support eliminating crossborder impediments and improving the 
condition of the regional road network, which limits intraregional trade and contributes to the high prices of food products in West Africa. (V.C, 2001)

\section{Conclusion}

Indonesia as a country directly adjacent to Malaysia poses a challenge as well as a distinct advantage for the two countries. The nature of interdependence possessed by the two countries makes good economic cooperation in the border area. Border communities whose economic interactions are in direct contact with neighboring countries feel the impact of the spread of the Covid-19 virus. With the spread of the Covid-19 virus in Malaysia, the government has implemented a lockdown policy and an appeal to stay at home, to reduce the number of Covid-19 spreads in the community.

However, this has changed Indonesia's economic conditions, especially for SMEs. The implementation of this lockdown hampers the pace of production and narrows the market for MSME players who usually only rely on immigrants or export to neighboring countries. Knowing this, the government assists in the form of venture capital funds to MSME actors to help Indonesian MSMEs continue to exist during this Covid-19 pandemic. With the worsening situation in Indonesia, which is marked by the continued increase in Covid19 sufferers, the government has disbursed a very large amount of health funds. So that the government finally implemented the New Normal policy, which means that activities outside the home can be done but with the health protocols that have been set by the government. Based on the implementation of the policies carried out by the Indonesian government, the authors argue that the government's efforts to save MSMEs have been very maximal. It is proven by the government's attention to the economy in Indonesia, which is getting worse, thus changing the lockdown policy to a new normal. It can be concluded that the spread of the Covid19 virus has brought changes to the policies implemented by the government. In addition to changing economic behavior in Indonesia, the Covid-19 pandemic has also changed the social behavior of people who always use masks and wash their hands when using public facilities. With the New Normal policy, conditions in Indonesia have started to stabilize until now, even though the Covid-19 pandemic is still 
ongoing. Here the author, the government, and the people of Indonesia certainly hope that the spread of Covid-19 can decrease, and the existing vaccines are easy to obtain so that economic and social activities can run freely as before.

Food security is one of the components that form the basic needs of a nation, households, and individuals. Any disruption at the dimensions of availability, accessibility, utilization, and stability of food security will threaten the security and wellbeing of citizens. Although food availability at the national level is guaranteed through local production and imports, the accessibility and utilization dimensions are not yet fulfilled as certain groups are still unable to access and utilize adequate food. Therefore, this research aims to examine the coping mechanisms adopted by Malaysian households among communities in the Indonesia- Malaysia border area by using the human security approach. The findings indicate that the households adopted several coping mechanisms, as well as utilizing external assistance programs to reduce the impact of food insecurity. Coping mechanisms, which made a difference in reducing vulnerability to food insecurity, varied among households depending on the resources available. However, these mechanisms should be further scrutinized by relevant agencies to understand the longterm impact on the affected households. Realizing this fact, the government should consider adopting the human security concept, which emphasizes community empowerment as a framework in policymaking, with the aims to eradicate food insecurity among vulnerable households and to ensure the well-being of every Indonesian.

\section{References}

Archer, C (1992). International Organization Third Edition: Writings on International Organization Interpendence. London and New York : Taylor \& Francis e-Library.

Cahya, V (2020). Pemberlakuan New Normal Di Beberapa Wilayah Indonesia. Retrieved 14 Maret 2021.

From https://kabarwarta.id/detailpost/pe mberlakuan-new-normal-dibeberapa-wilayah-di-indonesia

Ikatan Dokter Indonesia (2020). Pedoman Pencegahan dan Pengendalian Coronavirus Disease (COVID-19), 151-154.Kementrian Kesehatan 
RI.Kementrian Kesehatan (2020). Infeksi Emerging, Retrieved Mei 11, 2021. from https://infeksiemerging.kemkes.go. id/downloads/?dl_cat=0\&dl_search $=$ covid $\# . X 1$ naDmgzaMo

Kementrian Luar Negeri, Konsulat Jenderal Republik Indonesia di Penang Malaysia : Hubungan Bilateral.

Retrieved Mei 11, 2021

KOMINFO (2020). Kebijakan Pemerintah Dukung UMKM Untuk Menggerakkan Ekonomi. Retrieved 14 Maret, 2021. from https://www.kominfo.go.id/content /detail/30581/kebijakanpemerintah-dukung-umkm-untukmenggerakkan-ekonomi/0/berita

Kompas (2020). Pandemi Covid-19, Apa Saja Dampak pada Sektor Ketengakerjaan Indonesia?. Retrieved 14 Maret 2021. from https://www.kompas.com/tren/read /2020/08/11/102500165/pandemicovid-19-apa-saja-dampak-padasektor-ketenagakerjaan-indonesia?page=all

Kompas.com - 14/11/2020, "Gara-gara Malaysia Lockdown, Harga Elpiji di Krayan Rp 1,5 Juta, Semen Rp 1,8 Juta Per
Zak"， https://regional.kompas.com /read/2020/11/14/15505231/garagara-malaysia-lockdown-hargaelpiji-di-krayan-rp-15-juta-semenrp-18?page=all.

Penulis : Kontributor Nunukan, Ahmad Zulfiqor

Moedjiono, A (2020). Sejarah Panjang Virus Corona, Retrieved Mei 11, 2021, from https://bebas.kompas.id/baca/opini/ 2020/04/08/sejarah-panjang-viruskorona/

Mutia, A dkk (2014). Kerjasama Sosial dan Ekonomi Indonesia-Malaysia: Jurnal Tesis PMIS-UNTAN-PSIP. hlm. 6-8

Nugrahaningsih, N (2015). Kerjasama Bilateral Indonesia-Malaysia: Studi Tentang Sosek Malindo dalam Pembangunan Pos Pemeriksaan Lintas Batas di Jagoi Babang Kabupaten BengkayangKalimantan Barat. Jurnal Unpad. hlm. 22-26.

Nugroho, I (2020). Upaya Pemerintah Selamatkan UMKM di tengah pandemi. Retrieved 16 Maret, 2021. from https://www.liputan6.com/bisnis/re ad/4350581/sederet-upaya- 
pemerintah-selamatkan-umkm-di-

tengah-pandemi

Pane, M (2021). Virus Corona, Retrieved Maret 30, 2021. from https://www.alodokter.com/viruscorona

Perwita \& Yani (2005). Pengantar ilmu hubungan internasional. Bandung : Remaja Rosdakarya.

Putra, A (2015). Hubungan Kerjasama Perbatasan Indonesia-Malaysia : Jurnal Hukum IUS QUIA IUSTUM, hlm. 309-312.

Siburian, R. (2012). Pulau Sebatik: Kawasan perbatasan Indonesia beraroma Malaysia. Jurnal Masyarakat dan Budaya, 14(1)

Simanjorang, S (2020). Nasib UMKM di Tengah Pandemi Covid-19. Retrieved 14 Maret 2021. from https://investor.id/opinion/nasibumkm-di-tengah-pandemi-covid19 Syamsudin, M (2020). Dampak Pandemi Covid-19 terhadap UMKM di Indonesia. Retrieved Maret 4, 2021. from https://www.nu.or.id/post/read/123 247/dampak-pandemi-covid-19terhadap-umkm-di-indonesia
Wawancara dengan, Cholilatul (Penjual Aneka Kripik). 10 Juli 2020, 20.00 WITA.

Wawancara dengan, Dila (Penjual Milkshake). 10 Juli 2020, 03.00 WITA.

Wawancara dengan, Harman, S.IP, M.AP (Kabid Perdagangan Disperindag Kab.Nunukan). $18 \quad$ September 2020, 10.32 WITA.

Wawancara dengan, Markup (Penjual Aneka Kripik). 10 Juli 2020, 03.00 WITA.

Wawancara dengan, Sarlan (Penjual Ikan Bandeng). 19 September 2020, 01.00 WITA.

Wawancara dengan, Siti Hasna (Kabid Pemberdayaan dan Pengembangan Koperasi dan UMK, Disperindag Kab.Nunukan). $18 \quad$ September 2020, 11.35 WITA.

Wawancara dengan, Sri Muryati (Penjual Nasi Kuning). 20 September 2020, 08.00 WITA.

Wawancara dengan, Sutrisno (Penjual Tahu Tek). 19 September 2020, 20.00 WITA.

Yanuar, I (2006). Ekonomi Politik Internasional Konsep dan Teori. Bandung : PT. Refika Aditama. 


\begin{tabular}{|l|l|}
\hline \hline MANDALA : & Vol.4 No.2 \\
Jurnal Ilmu Hubungan Internasional & Juli-Desember \\
\hline
\end{tabular}

Prodi Ilmu Hubungan Internasional FISIP UPN”Veteran” Jakarta 